\title{
Penerapan Soft Sistem Methodelogy Pada Pengembangan Sistem Informasi Akademik (Studi Kasus di SMKN 6 Kota Bekasi)
}

\author{
Ani Yoraeni ${ }^{1,},{ }^{\star}$, Henny Leidiyana ${ }^{2}$ \\ ${ }^{1}$ Sistem Informasi; Universitas Nusa Mandiri; Jalan Jatiwaringin No 2 , Cipinang \\ Melayu Jakarta , Telp (021)8005722. e-mail: ani.ayr@nusamandiri.ac.id \\ 2 Sistem Informasi; Universitas Bina Sarana Informatika, Jalan Kramat Raya No 98, \\ Jakarta. Telp (021)23231170; e-mail: henny.hnl@bsi.ac.id \\ * Korespondensi: e-mail: ani.ayr@nusamandiri.ac.id
}

Diterima: 6 Juli 2021; Review: 6 Juli 2021; Disetujui: 7 Juli 2021; Diterbitkan: 8 Juli 2021

\begin{abstract}
Academic information systems are important in teaching and learning activities, this is supported by adequate facilities and infrastructure. To support this, a system must be made that is able to assist in the teaching and learning process, namely by developing an academic information system. This development system uses the social system methodology method with the aim of helping the school's academic field achieve its goals and facilitate the teaching and learning process. This approach is designed using CATWOE analysis with components, namely customers, actors, the transformation process, world view, and the environment. The results of this study are able to answer the school's need for an effective and efficient system so that it can improve the performance of all school goals.
\end{abstract}

Keywords: Academic information systems, Soft systems methodology

\begin{abstract}
Abstrak
Sistem Informasi akademik merupakan hal penting dalam kegiatan belajar mengajar, hal ini ditunjang dengan sarana dan prasana yang memadai.Untuk menujang hal tersebut maka harus dibuatkan system yang mampu membantu dalam proses kegiatan belajar mengajar, yaitu dengan adanya pengembangan system informasi akademik. Pemgembangan system ini menggunakan metode sosft system methodologi dengan,tujuan untuk membantu bidang akademik sekolah mencapai tujuan dan memudahkan dalam proses kegiatan belajar mengajar. Pendekatan ini rancangannya menggunakan analisis CATWOE dengan komponen yaitu pelanggan, actor, proses transformasi, pandangan dunia, pemilik dan kendala lingkungan. Hasil dari penelitian ini mampu menjawab kebutuhan sekolah akan sistem yang efektif dan efisien sehingga bisa meningkatkan kinerja seluruh cititas sekolah.
\end{abstract}

Kata Kunci: Sistem Informasi akademik, Soft sitem methodology

\section{Pendahuluan}

SMKN 6 Kota Bekasi merupakan sekolah milik pemerinta yang terletak di tengah kota Bekasi, sebagai salah satu sekolah yang sudah terakreditasi A,sudah seharusnya untuk meningkatkan kualitas dikarenakan ketatnya persaingan dengan lembaga pendidikan lainnya.Salah satu upaya peningkatan pelayanan kepada siswa yaitu dengan membangun aplikasi sistem informasi akademik berbasis web. Penggunaan teknologi informasi dan komunikasi didunia pendidikan ini akan semakin meningkat manfaatnya dan merupakan 
sebagai suplemen yang penting buat para siswa serta manajemen sekolah (Kadek Wibowo, 2015)

Kesulitan yang sering dihadapi oleh bagian akademik SMK N 6 Kota Bekasi dalam mengelola data siswa adalah dalam penyimpanan, pencarian, penambahan dan perubahan data, ini disebabkan oleh masih digunakannya sistem berkas dalam mengelola data siswa. Sistem informasi ini dapat memberikan banyak kemudahan dalam proses pengolahan data, dimana proses pengolahan data yang biasa dilakukan secara manual bisa diterapkan menjadi sistem komputerisasi yang terintegrasi, sehingga data dapat disimpan secara terstruktur dan lebih mudah untuk dikelola.

Soft System Methodology (SSM) adalah suatu metode yang digunakan dimana proses yang melibatkan lingkungan dengan hubungan relevan antara yang nyata dengan sistem (model konseptual), dengan tujuan dapat menemukan dan mendefinisikan masalah yang memberikan alternatif perubahan dari sistem sebelumnya(Hindle, 2012)

Soft Systems Methodology (SSM) dapat digunakan sebagai cara untuk menggambarkan pendekatan dalam penyampaian knowledge dari proses sistem akademik. Metode ini memberikan proses gambaran secara menyeluruh mengenai kegiatan proses belajar mengajar sehingga penyampaian knowledge yang lebih maksimal. Dari beberapa penelitian yang ada sebelumnya bahwa model SSM cocok digunakan untuk pengembangan sistem informasi akademik. Penelitian ini bertujuan untuk menghasilkan pemodelan sistem informasi akademik dengan menggunakan metode Soft Systems Methodology (SSM) sebagai penyelesaiannya .

Penerapan Soft Systems Methodology (SSM) dengan analisis CATWOE sangat mendukung untuk perkembangan model yang digunakan untuk menggambarkan pengembangan sistem informasi akademik. Tujuan pendekatan metode SSM membantu bidang akademik sekolah mencapai tujuan untuk memudahkan dalam proses kegiatan belajar mengajar.

Penelitian sebelumnya mengenai soft sistem management yang berjudul "Aplikasi Soft Sistem Methodology dalam analisis diplomasi angkatan laut Indonesia melalui pengiriman satgas maritime TNI pada misi UNIFIL MTF, hasil peneltian tersebut adalah untuk menjaga perdamaian dunia yang merupakan mandat secara konstitusi dalam upaya meningkatkan peran global indonesia sebagai middle power maka Indonesia perlu menggerakan TNI untuk mengirim satgas Maritin TNI, sebagai naval diplomacy pada bahasan perbandingan model konseptual dengan dunia nyata menggiring pada saran tindak untuk owners of the issue addresse (Sirmareza, 2017)

Pada penelitian yang berjudul Aplikasi Soft System Methodology (SSM) untuk perancangan terintegrasi biofull dalam sektor pertanian dan sektor energi menjelaskan bahwa melalui tujuh tahap dalam pendekatan soft sistem methodology (SSM) dengan mendefinikan CATWOE pada perencanaan yang terintegrasi biofuel dalam sektor pertanian dan sektor energy, diperoleh hasil penelitian bahwa dari biodesel maupun bioethanol, kedua nya memiliki 
potensi yang besar sebagai pengganti bahan bakar minyak di Indonesia. Untuk mencapai hal tersebut maka diperlukan langkah yang nyata dalam mempersiapkan teknologi bahan bakunya. serta dibutuhkan kebijakan pemerintah dalam penggunaan bahan bakar. Bantuan pemerintah untuk pembukaan lahan yang kritis serta dukungan teknologi budidaya tanaman dan diperlukan untuk mendistribusikan ke pasar-pasar. Oleh sebab itu diperlukan adanya perencanaan yang saling bersinergis antara sektor pertanian, ekonomi dan energi dengan platform modified LEAP (Firdaus \& Maarif, 2015).

Pada penelitian yang berjudul "Using Soft System Methodology (SSM) in Understanding the Problem of Cheating in the National Examination" menyatakan bahwa Penilaian prestasi siswa masih berorientasi pada evaluasi akhir daripada evaluasi proses. Ini memiliki kelemahan yang mengarah pada evaluasi sesaat siswa. Hal tersebut didukung oleh kurangnya rasa percaya diri siswa yang menyebabkan perasaan cemas diantara siswa dan orang tua (Iriani \& Manongga, 2018)

Pada penelian ini yang berjudul "Analisa kebutuhan e-learning untuk pengembangan mutu KBM dengan soft sistem methodologi pada SMK di Semarang" meberikan hasiil dengan menggunakan model Soft Sistem methodologi dengan analisa CATWOE di peroleh gambaran gambaran secara menyeluruh mengenai kegiatan proses belajar mengajar sehingga penyampaian knowledge yang lebih maksimal. (Rasminto et al., 2020)

Proses SSM dilakukan melalui 7 (tujuh) tahap (Hardjosoekarto, 2012) yang digambarkan oleh gambar berikut ini :

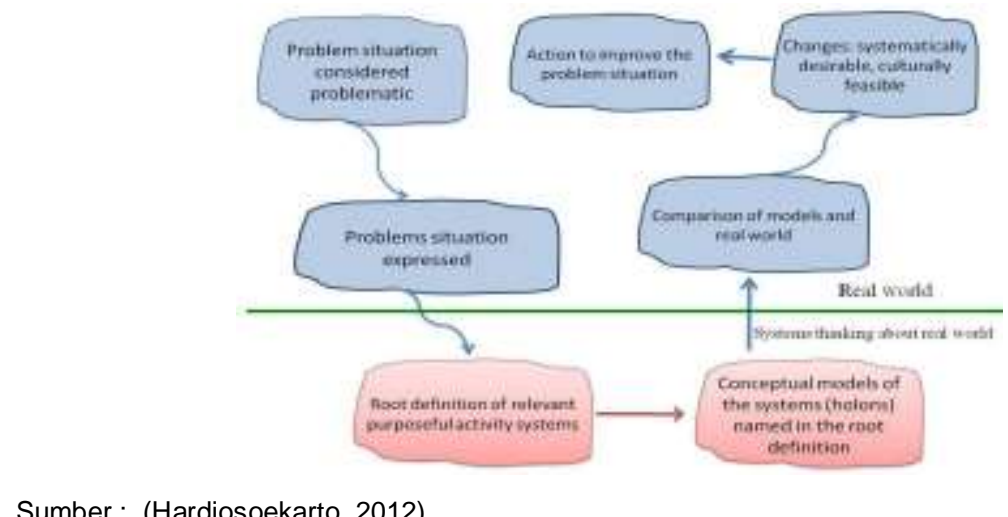

Gambar 1. Tahapan pada SSM

Adapun tahapan-tahapan yang dimaksud adalah (Hananto \& Septiani, 2020) :

1. Mencari permasalahan yang dihadapi kemudian menuangkannya dalam bentuk Rich Picture untuk bisa dipahami aktivitas permasalahan yang terjadi.

2. Mendefiniskan permasalahan dengan jelas serta mengumpulkan data dan informasi kemudian dilanjutkan dengan formulasi \& presentasi masalah-masalah kemudian dituangkan dalam bentuk Rich picture. 
3. Memformulasi sistem yang relevan dengan melihat keterkaitan masalah dengan sistem yang ada kemudian membangun sistem aktivitas manusia menggunakan analisis CATWOE.

4. Merancanng model konseptual berdasarkan identifikasi pada situasi nyata elemen kemudian memformulasikan sistem guna mencapai tujuan.

5. Membandingkan model dengan yang sudah dibangun dengan situasi nyata sehingga didapatkan ide perubahan yang bisa diterapkan guna perbaikan model konseptual.

6. Melakukan perbaikan melalui identifikasi tahapan-tahapan yang sudah dilakukan yang memunculkan perubahan-perubahan yang sistematis dan layak untuk dilakukan setelah perbandingan dengan keadaan nyata.

7. Implementasi melakukan tindakan melalui perubahan-perubuhan yang didapatkan pada tahap sebelumnya.

Tabel 1. Elemen CATWOE

\begin{tabular}{l|l|l}
\hline \multicolumn{2}{c|}{ Elemen CATWOE } & Keterangan \\
\hline & Customer & $\begin{array}{l}\text { Penerima manfaat ataupun akibat dari sistem atau proses } \\
\text { tranformasi }\end{array}$ \\
\hline & Actor & Orang-orang yang melakukan proses transformasi \\
\hline & Transformation & Konversi dari input ke output \\
\hline & Weltanschauun & $\begin{array}{l}\text { Prespektif atau cara pandang yang membuat transformasi } \\
\text { menjadi berarti }\end{array}$ \\
\hline & Owner & $\begin{array}{l}\text { Orang/ kelompok yang bertanggung jawab yang dapat } \\
\text { menghentikan transformasi }\end{array}$ \\
\hline & Environment & Lingkungan di luar sistem yang diberikan \\
\hline
\end{tabular}

Sumber :(Hany Makaruku et al., 2019)

\section{Metode Penelitian}

Berikut adalah tahapan metode penelitian yang digunakan adalah :

\subsection{Pengumpulan data}

\section{a. Observasi}

Observasi dilakukan untuk pengambilan informasi dan mempelajari sistem akademik yang berjalan di SMKN 6 Kota Bekasi, sehingga dapat dirumuskan untuk pengembangan sistem yang efektik dan efisien..

\section{b. Wawancara}

Metode wawancara digunakan untuk mendapatkan informasi keadaan sebenarnya proses wawancara ini melibatkan 3 responden, yaitu : orangtua siswa, siswa, staff TU dan guru.

\subsection{Analisa}

Pada tahapan analisa ini menganalisa apa saja kebutuhan yang akan digunakan dalam pengembangan sistem informasi akademik. Metode penelitian untuk merancang sistem 
informasi akademik di SMKN 6 Kota Bekasi yaitu menggunakan pendekatan dengan Soft System Methodology (SSM). SSM merupakan metode yang digunakan untuk menganalisa berbagai macam masalah situasi riil, yang kompleks serta konseptual paradigmatik di lingkungan sosial, ekonomi, politik ataupun pada tataran kebijakan sehingga metode SSM bisa dikatakan metode yang unik (Hidayatullah, 2011).

Menurut (Firdaus \& Maarif, 2015) Ide dasar dari Soft System Methodelogi (SSM) merupan konsep sistem yang digunakan untuk menyelidiki permasalahan dunia nyata kemudian dipersepsikan. Ide-ide sistem ini berdasarkan konsep 'a whole' dimana suatu organisasi dapat dilihat sebagai suatu keseluruhan yang utuh serta keseluruhan (the whole) lebih berarti dari pada jumlah bagian-bagiannya. SSM adalah sebuah pendekatan berbasis sistem yang dikembangkan sebagai cara untuk menggunakan konsep sistem dalam organisasi (sosial) untuk melakukan intervensi dan memahami usaha mereka (Sgourou et al., 2012). Pendekatan SSM dimulai dengan mengidentifikasi permasalahan yang terjadi dunia nyata yang oleh orang yang mempunyai kepentingan. Gambaran situasi bertujuan untuk membuat diagnosis situasi yang ada, mengidentifikasi peserta dan masalah alam. Strategi yang paling umum adalah representasi grafis dari masalah yang diteliti. Representasi grafis ini, yang disebut "gambar kaya", mencakup semua pemangku kepentingan dan hubungan mereka untuk menawarkan pandangan luas tentang masalah ini pendekatan SSM membangun model konseptual (Binsar Tampahan Siagian, 2010), dimana harus memiliki definisi sistem yang jelas untuk dimodelkan, yang rancangannya di pandu dengan komponen CATWOE yaitu pelanggan, actor, proses transformasi, pandangan dunia, pemilik dan kendala lingkungan.

\section{Hasil dan Pembahasan}

Untuk mengimplemtasikan Soft System Methodology dalam pengembangan sistem informasi akademik di SMKN 6 Kota Bekasi dalam upaya peningkatan kualitas pelayanan bagi siswa dan guru serta tata usaha, maka dilakukan langkah-langkah yang ada pada tahapan SSM sebagai berikut :

\section{a. Deskripsi permasalahan}

Masalah Sistem Informasi Akademik yang belum terkomputerisasi/manual. Sitem yang berjalan pada saat ini di SMKN 6 masih menggunakan aplikasi Microsoft Office Word dan Excel. Microsoft Word digunakan untuk pembuatan surat seperti,surat tugas untuk guru, surat perpindahan siswa ke sekolah lain, surat panggilan wali murid, surat izin untuk siswa, dan surat penting lainnya sedangkan Microsoft Excel digunakan untuk membuat data sekolah yang bersifat tabel, seperti data absensi siswa dan guru, data kelas dan data nilai siswa, data guru dan jadwal mengajar. Selain itu dalam penyampaian informasi tentang jadwal pelajaran siswa, data nilai siswa, kalender akademik, pengumuman hasil kelulusan, rapat dengan wali murid masih menggunakan papan pengumuman atau majalah dinding (mading) di sekolah sehingga siswa kesulitan dalam mencari informasi- informasi tersebut bila siswa tidak berada di sekolah. 
Selain itu, Staff Tata Usaha (TU) akan pusing apabila akan menjelaskan dan menjawab pertanyaan dari siswa yang ingin bertanya tentang informasi data - data tersebut.

\section{b. Rich Picture untuk menggambarkan permasalahan}

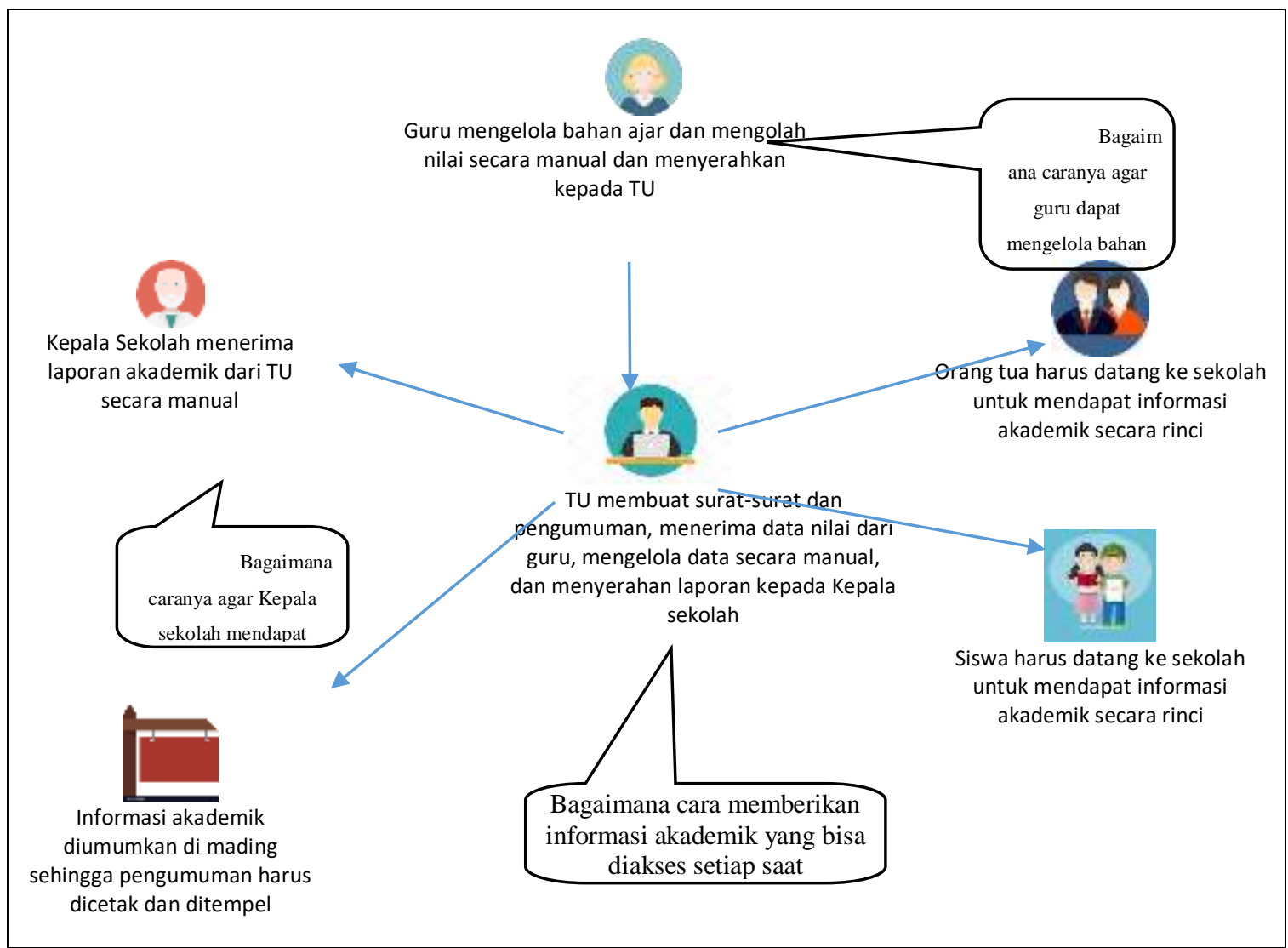

Sumber : Hasil Penelitian(2021)

Gambar 2. Rich Picture

\section{c. Root Definition}

Root definition dari permasalahan yang ada pada sistem informasi akademik sebagai berikut :

- $\mathrm{X}$ : Apa yang sistem akan lakukan

- Y: Bagaimana sistem mengerjakan

- Z: Mengapa sistem melakukan

Maka rumusan dari bentuk 'root definition' adalah Sekolah dapat menggajukanpembuatan Sistem Informasi yang terintegrasi dengan sistem informasi akademik yang digunakan oleh SMKN 6 Kota Bekasi untuk melakukan proses kegiatan belajar mengajar, penjadwalan, dan penginputan nilai hasil belajar $(\mathrm{X})$. Sistem Informasi tersebut dikerjakan oleh unit sistem informasi atau TIM ICT sehingga pada tahun berikutnya dapat digunakan (Y). Sistem Informasi ini dibuat dengan tujuan agar proses kegiatan belajar mengajar semakin efektif dan efisien serta mengurangi jumlah berkas yang ada di administrasi tata usaha karena akan digunakan database yang dapat diakses oleh staff tata usaha, guru, siswa dan orang tua (Z). 
Tabel 2. Elemen CATWOE

\begin{tabular}{|c|c|}
\hline Elemen CATWOE & Deskripsi \\
\hline $\begin{array}{l}\text { - } \text { Customer (penerima manfaat ataupun } \\
\text { akibat dari sitem atau proses transformasi) } \\
\text { - Actor (orang-orang yang melakukan proses } \\
\text { transformasi) } \\
\text { - Transformation (konversi dari input ke out) } \\
\text { - Weltanschauung/World view (prespektif } \\
\text { atau cara pandang yang membuat } \\
\text { transformasi menjadi berarti) } \\
\text { - Owner (orang/ kelompok yang bertanggung } \\
\text { jawab yang dapat menghentikan } \\
\text { transformasi (lingkungan di luar sistem } \\
\text { - Environment } \\
\text { yang diberikan) }\end{array}$ & $\begin{array}{l}\text { Kepala sekolah, Guru, TU, orang tua } \\
\text { wali dan siswa } \\
\text { SIswa, Guru, TIM ICT, TU } \\
\text { Sistem akademik akan terkontrol } \\
\text { Dengan melihat Rich Picture, } \\
\text { menggambarkan hubungan antar } \\
\text { objek } \\
\text { Sekolah }\end{array}$ \\
\hline
\end{tabular}

Sumber : Hasil Penelitian (2021)

\section{d. Model konseptual dari root definition}

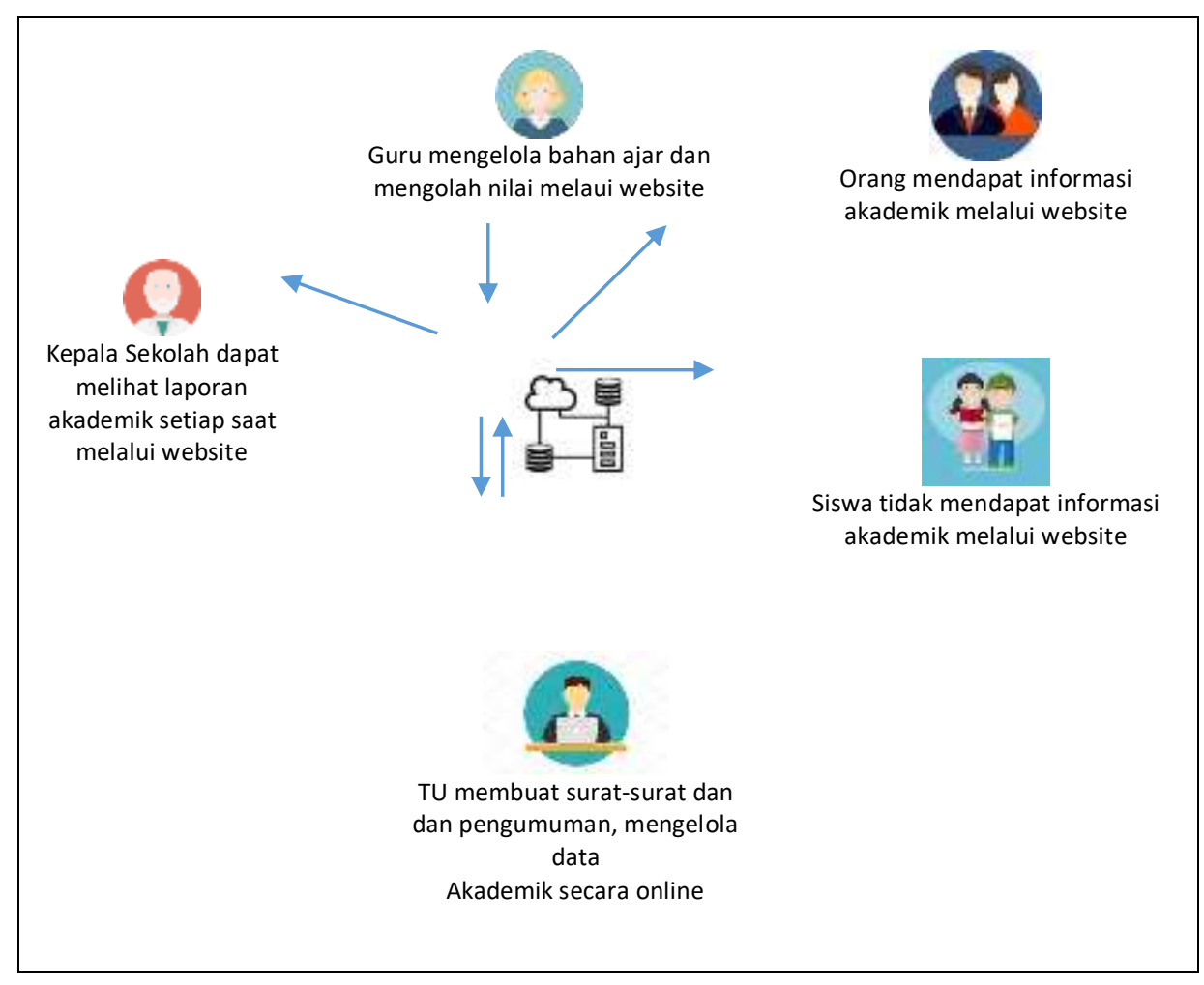

Sumber : Hasil Penelitian (2021)

Gambar 3. Rich Picture 
Tabel 3. Ukuran Performansi

\begin{tabular}{ll}
\hline Ukuran Performansi & \multicolumn{1}{c}{ Keterangan } \\
\hline - E1 (efficacy) & $\begin{array}{l}\text { Apakah penggunaan sistem informasi akademik dapat } \\
\text { mengurangi kesalahan-kesalahan yang sering terjadi pada } \\
\text { saat kegiatan KBM, input data atau pun nilai? }\end{array}$ \\
& $\begin{array}{l}\text { Apakah dengan menggunakan s istem informasi akademik } \\
\text { dapat menghemat waktu dalam pengolahan data ? }\end{array}$ \\
- E2 (efficiency) & $\begin{array}{l}\text { Apakah penggunaan sistem informasi akademik } \\
\text { merupakan solusi yang paling tepat untuk mengatasi } \\
\text { permasalahan yang terjadi pada proses KBM, input data } \\
\text { dan olah data? }\end{array}$ \\
\hline
\end{tabular}

Sumber : Hasil penelitian (2021)

\section{e. Membandingan dengan situasi sebenarnya}

Pada tahap ini, sesudah model konseptual di perloleh, maka selanjutnya membandingkan model konseptual dengan dunia sebenarnya yang akan merekomendasikan hal apa saja yang harus pertahankan dan apa saja yang harus di perbaharui atau di perbaiki, dalam rangka untuk menigkatkan hal baru yang perlu di buat. Rekomendasi yang disampaikan dalam proses tersebut mencakup enam poin yaitu :

Tabel 4. Activity

\begin{tabular}{|c|c|c|}
\hline Activity & $\begin{array}{l}\text { Apakah sudah selesai dan } \\
\text { sesuai dengan situasi? } \\
\text { Bagaimana melakukannya? }\end{array}$ & Rekomendasi \\
\hline $\begin{array}{l}\text { - Activity Pengolahan } \\
\text { Data Siswa }\end{array}$ & Sudah berjalan dengan baik & N/A \\
\hline $\begin{array}{lll} & \text { Activity Pengolahan } \\
& \text { Data Guru }\end{array}$ & Sudah berjalan dengan baik & N/A \\
\hline $\begin{array}{llr}\text { - } & \text { Activity } & \text { Diagram } \\
& \text { Pengolahan } & \text { Data } \\
& \text { Absen } & \\
\end{array}$ & Sudah berjalan dengan baik & $\mathrm{N} / \mathrm{A}$ \\
\hline $\begin{array}{llr}\text { - } & \text { Activity } & \text { Diagram } \\
\text { Pengolahan Data Nilai } \\
\text { Tugas }\end{array}$ & $\begin{array}{l}\text { Masih ada beberapa guru } \\
\text { yang bingung input nilainya }\end{array}$ & $\begin{array}{l}\text { Diadakan pelatihan } \\
\text { untuk para guru }\end{array}$ \\
\hline 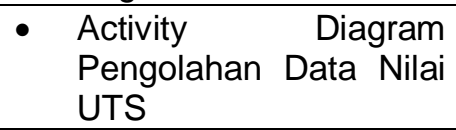 & $\begin{array}{l}\text { Masih ada beberapa guru } \\
\text { yang bingung input nilai UTS }\end{array}$ & Diadakan pelatihan \\
\hline $\begin{array}{ll}\text { - } & \text { Activity pengolahan } \\
\text { jadwal pelajaran }\end{array}$ & Sudah berjalan dengan baik & $\mathrm{N} / \mathrm{A}$ \\
\hline
\end{tabular}

Sumber : Hasil Penelitian (2021)

\section{f. Perubahan yang mungkin dilakukan dan aksi untuk perbaikan situasi}

Melakukan perbaikan/solusi untuk sistem yang direkomendasikan (action to improve the problem situation), fase akhir adalah melakukan rekomendasi-rekomendasi perbaikan terhadap sistem yang lama 
Tabel 5. Perubahan

\begin{tabular}{l|ll}
\hline Perubahan yang dapat dilakukan & \multicolumn{2}{|c}{ Aksi perbaikan } \\
\hline - $\begin{array}{l}\text { Sosialisasi kepada siswa guru } \\
\text { dan TU }\end{array}$ & $\bullet \begin{array}{l}\text { Melakukan pembuatan jadwal } \\
\text { sosialisasi setelah sistem dibuat }\end{array}$ \\
\hline $\begin{array}{l}\text { Training penggunaan sisitem } \\
\text { informasi akademik }\end{array}$ & $\bullet \begin{array}{l}\text { Melakukan pembuatan jadwal } \\
\text { training setelah sistem dibuat }\end{array}$ \\
\hline $\begin{array}{l}\text { Helpdesk mengumumkan } \\
\text { alamat akses end user manual } \\
\text { sistem dan call centre yang } \\
\text { dapat dihubungi }\end{array}$ & $\begin{array}{l}\text { Menyiapkan end user manual yang } \\
\text { baik. Mengumumkan alamat akses } \\
\text { manual dan call centre yang dapat } \\
\text { dihubungi }\end{array}$ \\
\hline $\begin{array}{l}\text { Perlu dilakukan monitoring } \\
\text { sampai proses bulanan berjalan } \\
\text { stabil }\end{array}$ & $\bullet \begin{array}{l}\text { Review hasil proses bulanan } \\
\text { beberapa kali }\end{array}$ \\
\hline
\end{tabular}

Sumber : Hasil Penelitian (2021)

\section{g. Implementasi melakukan tindakan melalui perubahan-perubuhan yang didapatkan pada tahap sebelumnya}

Setelah memperhatikan dilapangan ada beberapa hal temuan yang harus diperbaiki, baik secara internal maupun internal. Peneliti mengusulkan beberapa perencanaan perubahan sebagai berikut :

1. Perlu adanya pembangunan fasilitas untuk mendukung proses belajar-mengajar yang efektif dan efisien sehingga bisa mempermudah pekerjaan

2. Melakukan kerja sama dengan pihak luar agar bisa meringankan dalam penyediaan fasilitas baik secara materi maupun non materi

3. Harus ada maintenance sistem secara berkala untuk meniminalisir terjadinya kerusakan sistem

4. Melakukan back up data untuk menghindari jika terjadinya kehikangan data.

\section{Kesimpulan}

Dari pembahasan diatas maka dapat di tarik kesimpulan bahwa dengan analisa pedekatan soft sistem methodology untuk pengembangan sistem informasi akademik pengguna bisa menggambarkan secara utuh permasalahan yang terjadi pada sistem sebelumnya, dengan ada nya SSM maka sistem implementasisnya merupakan sistem thinjing human activity, dan diharapkan apa yang sudah di bangun bisa mencapai tujuan sesuai dengan harapan.

\section{UCAPAN TERIMA KASIH}

Ucapan terima kasih peneliti sampai kan kepada Kepala SMKN 6 Kota Bekasi yang sudah memberikan waktu dan kesempatan untuk melakukan penelian ini, juga kepada para guru, Staff TU dan siswa..

\section{Daftar Pustaka}

Binsar Tampahan Siagian, D. I. S. (2010). Pemetaan dan Analisis Knowledge Sharing Pada Situs Forum Komunitas Online Kaskus. Jurnal Sistem Informasi MTI-UI, 6(1), 38-53.

Firdaus, A., \& Maarif, M. (2015). Aplikasi Soft System Methodology (Ssm) Untuk Perencanaan 
Terintegrasi Biofuel Dalam Sektor Pertanian Dan Sektor Energi. Jurnal PASTI, 9(1), 1-9.

Hananto, A., \& Septiani, W. (2020). Pendekatan Soft System Methodology Untuk Perancangan Model Pembelajaran Praktik Berbasis Produksi. 10(1), 53-65.

Hany Makaruku, Y., Sediyono, E., \& Sembiring, I. (2019). Pemodelan Knowledge Dalam Proses Pemberian Beasiswa Bagi Mahasiswa Menggunakan Soft System Methodology (SSM) (Studi Kasus: Fakultas Keguruan dan IImu Pendidikan Universitas Pattimura Ambon). Jurnal Teknik Informatika Dan Sistem Informasi, 5(1), 122-130. https://doi.org/10.28932/jutisi.v5i1.1587

Hardjosoekarto, S. (2012). Soft Systems Methodology (Metode Serba Sistem Lunak). Universitas Indonesia (UI-Press).

Hidayatullah, H. (2011). SSM, Sebuah Pendekatan Holisitik untuk Kegiatan Aksi (Learning For Actions). Jurnal Sosiologi Islam, 1(2), 109-116.

Hindle, G. A. (2012). Case Studies in Service Innovation. January 2012. https://doi.org/10.1007/978-1-4614-1972-3

Iriani, A., \& Manongga, D. (2018). Using soft systems methodology as an approach to evaluate cheating in the national examination. Journal of Theoretical and Applied Information Technology, 96(11), 3344-3355.

Kadek Wibowo. (2015). Penerapan Sistem Informasi Akademik Berbasis Web ( Studi Kasus MTs . Maulana Ishaq Banyuwangi ). AMIK Bina Sarana Informatika Jakarta, 119-124.

Rasminto, H., Silalahi, F. D., \& Hartono, B. (2020). Analisis Kebutuhan E-Learning Untuk Pengembangan Mutu KBM Dengan Soft System Methodology Pada SMK di Semarang . 13(2), 138-149.

Sgourou, E., Katsakiori, P., Papaioannou, I., Goutsos, S., \& Adamides, E. (2012). Using soft systems methodology as a systemic approach to safety performance evaluation. Procedia Engineering, 45, 185-193. https://doi.org/10.1016/j.proeng.2012.08.141

Sirmareza, T. (2017). Aplikasi Soft System Methodology dalam Analisis Diplomasi Angkatan Laut Indonesia melalui Pengiriman Satgas Maritim TNI Pada Misi UNIFIL MTF. Global: Jurnal Politik Internasional, 19(1), 58. https://doi.org/10.7454/global.v19i1.122 